\title{
Blood as an Important Tool in Criminal Investigation
}

\author{
Kristina Pokupcic* \\ Ministry of the Interior Zagreb 10000, Police College, Croatia
}

Submission: May 07, 2017; Published: May 24, 2017

*Corresponding author: Kristina Pokupcic, Ministry of the Interior Zagreb 10000, Police College, European Union, Croatia Tel: 0038598568558; Email: kristina.pokupcic@gmail.com

\begin{abstract}
Blood is one of the most important biological traces that are often found on the crime scene. Due to valuable information it contains, it is considered to be a very important forensic tool. Analysis of different aspects of bloodstains can contribute to clarify the circumstances under which some violent crimes have been committed. Such crucial information can point criminal investigation in the right direction and help solve the crime. In some cases it can also help with legal determination of criminal offense which can lead to more accurate and more appropriate punishment for the perpetrator. It is very important to determine the sequence of events during the commitment of a violent crime involving blood.

Analysis of different aspects of bloodstains includes appropriate methods from natural sciences, particularly methods in molecular biology and also from mathematics, physics and chemistry. Proper knowledge enables interpretation of results and makes it possible to get closer to the truth, solve that particular crime and bring the perpetrator to justice. After determining that it is blood by using serological tests, DNA profiles which account for the donors of different bloodstains are obtained. For the answers about sequence of events and mechanisms of creation of specific groups of bloodstains on the crime scene, investigation is pointed towards morphological analysis of bloodstains.
\end{abstract}

\section{Introduction}

Much valuable information can be obtained from only a single drop of blood by analyzing its chemical compounds as well as measurable morphological characteristics of the resulting bloodstains. Thorough research of bloodstains can provide crucial information about what has truly happened during the commission of a violent crime which resulted with different shapes of blood pattern on various kinds of surfaces. Since it involves multidisciplinary approach, forensic expert must have particular knowledge in order to be able to interpret the results of bloodstain analysis properly. Basic knowledge in natural sciences such as mathematics, biology and physics is a necessity, as well as some practical experience in criminal investigation of violent crimes including bloodstains. Having in mind those perquisites, well-trained and experienced expert can interpret bloodstains on the crime scene accurately and obtain valuable information about the source of bleeding, impact surface and mechanisms which led to the formation of bloodstains, give an indication of circumstances under which a particular criminal offense was committed and also help with its legal qualification.

When to use Bloodstain Analysis

The results of bloodstain analysis can distinguish between helping and deliberately injuring the victim, weather particular bloodshed event is an accident or not, or is it suicide or murder.

When this is not very obvious, thorough and committed analysis of bloodstains can clarify important circumstances and help solve the case. Taking into consideration all the assumptions for this specific kind of analysis, it must be kept in mind that this valuable tool should be used only if really necessary to obtain answers to specific questions regarding particular bloodshed event. Therefore, this method should not be used massively in every case involving bloodstains of some kind. Also, it should rely on the information obtained by DNA analysis concluding whose blood is it and also with the information about injuries inflicted during the commitment of that violent crime described in the autopsy report.

\section{Documentation of Bloodstains on the Crime Scene}

Proper documentation of all the details considering bloodstains on the crime scene is crucial for assuring their correct interpretation. Photographing all the bloodstains in as many details as possible and following a set of recommendations for taking photos of bloodstains is crucial for their interpretation even if crime scene is not accessible [1]. There are also computer programs that can be used for digital analysis of bloodstains, such as Back Track ${ }^{\circledR}[2,3]$. Also, 3D laser scanner can scan all 
the areas containing bloodstains and make extremely precise recording of the entire crime scene [4]. With appropriate software those images can be converted into virtual 3D models of a crime scene for their subsequent analysis [5].

\section{Serology and DNA Analysis}

Upon arrival on the crime scene of a violent crime, prior to start assessing morphological aspects of bloodstains, it is important to determine some of their basic characteristics. Serological presumptive tests are used to corroborate if a particular red drop on the crime scene is indeed human blood. Combur3 test benzidine strips or Kastle-Meyer phenolphthalein test confirm that the trace is blood and precipitin tests corroborate that it is human blood [6,7]. After applying serological tests it is important to determine whose blood is it on different objects and in different areas on the crime scene. In order to determine the donors of different kind of blood spatter throughout the crime scene, methods of DNA analysis should be applied. Since it was first used for solving a forensic case in the 1980's it has much developed and yielded a lot of forensic kits with great sensitivity which give remarkable results even with old and partially degraded blood. Some of them are SGM, Identifiler, NGM or Mini kits widely used to determine DNA profiles of the donors of blood, as well as other biological traces on the crime scene $[8,9]$.

This kind of analysis is itself quite expensive but gives statistically meaningful and undoubtedly accurate results. Even from a very small amount of blood of about $1 \mathrm{~mm} 2$ which consists of mathematically derived number of about 167 diploid cells containing nuclear DNA, DNA profile of a person can be extracted in a matter of hours $[8,9]$. The results of DNA analysis confirm that specific bloodstain or spatter is indeed from the victim or from the perpetrator, or maybe it is some kind of a mixture consisting of the blood of both donors. Relying on the results of DNA analysis it is also important to make correlation of bloodstains on the crime scene with inflicted injuries from the autopsy report and then morphological tests can be done [10].

\section{Properties of Blood}

Blood is a fluid with its mayor biological, chemical and physical properties which must be taken into account when analyzing bloodstains on the crime scene. Blood is liquid connective tissue which is consisted of blood cells and plasma. It is body fluid which accounts for about $7 \%$ of body weight of an average person, the total being 4-5 $\mathrm{l}$ for women and 5-6 $\mathrm{l}$ for men [11]. Blood is mainly used to transfer various substances throughout the body, as well as for defense from different kinds of pathogens [12]. An average person can survive rapid loss of about $1 / 3$ of total blood from the body and more than that can lead to death [11]. When bloodshed events happen, due to its physical and chemical properties blood spreads across the scene of a crime. Since placement and spreading of bloodstains obeys the laws of physics, there are mathematical methods which can be used to calculate the origin and the force applied to cause particular blood spatter [13]. Like any other fluid, blood has no shape of its own but when cast adjusts to its surroundings on various surfaces, textures and from different angles forming different shapes of stains on walls and furniture in a closed space such as a room. For morphological interpretation of blood cast throughout the crime scene basic knowledge about its physical characteristics such as specific weight, relative density, viscosity, surface tension, adhesion, cohesion and capillarity is essential [14].

\section{Information from Bloodstains on the Crime Scene}

One drop of blood can adhere to the smooth perpendicular surface by forming a round shape with pointed edges. If the angle of impact is not perpendicular, resulting bloodstain will be somewhat more ellipsoid [15]. Since impact angle is crucial to determine the position of the source of bleeding, it can be calculated using basic mathematical equations [13]. If the surface is not smooth it can break the surface tension of the droplet and lead to its breakdown so the resulting bloodstain cannot give accurate information about the impact angle. If surface is textile of some kind, especially made of natural fibers absorbing blood, calculating the impact angle is not possible. In that case information about when the crime was committed can be obtained by measuring time of clotting and capillary action of blood [16]. If blood is projected, cast-off some kind of murder weapon it will form lines throughout nearby surface and can give information about the number of blows or strikes during the commission of that violent crime [6].

Secondary bloodstains or satellites can give information about the whereabouts and movement of the victim and the perpetrator, and also help explain the dynamics of the commission of that crime, especially when there is more than one perpetrator and/or victim involved and there is more than one version on how it really happened. When violent crime is committed using firearm, resulting bloodstains can help determine the position of the shooter. In such cases three forms of bloodstains are important to mention. Forward spatter, on the trajectory of the bullet, back spatter on the hand that pulled the trigger and small amount of blood inside the muzzle of the firearm because of the drawback effect $[17,18]$. These bloodstains are very important to perceive on the crime scene, since the absence of back spatter on the victim's hand holding the weapon can clearly distinguish the event between murder and suicide [19]. Also, complementary to ballistic expertise, firearm appearing to be clean on the outside can contain victim's blood on the inside of the muzzle. The amount of blood can be very small, but as mentioned earlier it is sufficient for DNA analysis using specific and very sensitive biological kits. Lack of bloodstains can also be significant in the course of criminal investigation, because void areas can point to shapes of objects removed from the crime scene after the bloodshed event [7]. Imprints of bloody objects can give information about the shape 
of a murder weapon or help distinguish time sequence of events during the commission of a violent crime [6].

The results of morphological analysis of bloodstains can give a lot of valuable information and point an ongoing criminal investigation in the right direction. By using calculations, experiments and comparing results bloodshed event could be clarified to the details. By taking measurements of the ellipsoid shape of a dried blood drop the angle it was cast from can be determined. By measuring the time of drying the approximation can be made about the time crime was committed. By measuring the diameter and taking account of morphological characteristics depending on the properties of the surface it fell on, the height from which the blood was cast from can be determined.

\section{Conclusion}

Analysis of morphological aspects of blood is very important during criminal investigation of violent crimes involving blood traces, particularly violent crimes but also other types of criminal events where blood is one of the resulting evidence on the crime scene, such as traffic accidents or property crime. After determining whose is it, by analyzing all measurable characteristics of bloodstains left on the crime scene it can be determined was it a murder or a suicide, was the injury deliberate or was it the result of helping the victim, what was the sequence and the dynamics of events during the commission of the crime, approximately how long did it take to commit the crime and how much time has elapsed after the formation of those bloodstains, what are subsequent events that took place after the crime was committed, and which was the direction of movement of persons involved after the crime was committed.

Unfortunately, because of the predominance of DNA analysis which is most often used method of analyzing blood traces, analysis of morphological aspects of bloodstains is in most countries still not very developed and not widely used. It is also valuable to stress the importance of further education and specialization of forensic experts as well as all other involved in crime scene processing to produce knowledge and capacity of viewing bloodstains not only as DNA containing traces but also as a source of other valuable information that can help solve very serious violent crimes.

\section{References}

1. Wolson TL (1995) Documentation of bloodstain pattern evidence. J Forensic Ident 45(4): 396-408.

2. Illes MR, Carter AL, Laturnus PL, Yamashita AB (2005) Use of the Back Track $^{T M}$ Computer Program for bloostain pattern analysis of stains from downward-moving drops. Can Soc Forensic Sci 38(4): 213-218.

3. Carter AL, Forsythe Erman J, Hawkes V, Akira Brian Yamashita (2006) Validation of the BackTrack suite of programs for bloodstain pattern analysis. J Forensic Ident 56(2): 242-254.

4. Moore CC (2002) Three-dimensional models for bloodstain pattern analysis. J Forensic Identification 52(2): 183-203.

5. Buck U, Kneubuehl B, Nather S, Albertini N, Schmidt L, Thali M (2011) 3D bloodstain pattern analysis: Ballistic reconstruction of the trajectories of blood drops and determination of the centres of origin of the bloodstains. Forensic Sci Int 206(1-3): 22-28.

6. Peschel O, Kunz SN, Rothschild MA, Mutzel E (2011) Blood stain pattern analysis. Forensic Sci Med Pathol 7(3): 257-270.

7. Saferstein R (2015) Criminalistics: An Introduction to Forensic Science. Pearson Education, Inc, Upper Saddle River, New Jersey, USA.

8. Karger B, Rand S, Fracasso T, Pfeiffer H (2008) Bloodstain pattern analysis--casework experience. Forensic Sci Int 181(1-3): 15-20.

9. Butler JM (2010) Fundamentals of forensic DNA typing. (3 $3^{\text {rd }}$ edn), Burlington, Mass, Elsevier Academic Press, Massachusetts, USA.

10. Butler JM (2012) Advanced topics in forensic DNA typing: Methodology. Burlington, Mass, Elsevier Academic Press, Massachusetts, USA.

11. James SH, Kish PE, Sutton TP (2005) Principles of Bloodstain Pattern Analysis: Theory and Practice, CRC Taylor \& Francis, Boca Raton, Florida, USA.

12. James SH, Eckert WG (1998) Interpretation of Bloodstain Evidence at Crime Scenes, CRC, Boca Raton, Florida, USA.

13. Bevel T, Gardner RM (2008) Bloodstain Pattern Analysis. CRC, Boca Raton, Florida, USA.

14. Raymond MA, Smith ER, Liesegang J (1996) The physical properties of blood-forensic considerations. Sci Justice 36(4): 153-160.

15. Knock C, Davison M (2007) Predicting the position of the source of blood stains for angled impacts. J Forensic Sci 52(5): 1044-1049.

16. Karger B, Rand SP, Brinkmann B (1998) Experimental bloodstains on fabric from contact and from droplets. Int J Legal Med 111(1): 17-21.

17. Karger B, Nusse R, Schroeder G, Wustenbecker S, Brinkmann B (1996) Backspatter from experimental close-range shots to the head. I. Macrobackspatter. Int J Legal Med 109(2): 66-74.

18. Karger B, Nusse R, Troger HD, BrinkmannB (1997) Backspatter from experimental close-range shots to the head. II. Microbackspatter and

This work is licensed under Creative Commons Attribution 4.0 License DOI: 10.19080/JFSCI.2017.03.555615
Your next submission with Juniper Publishers will reach you the below assets

- Quality Editorial service

- Swift Peer Review

- Reprints availability

- E-prints Service

- Manuscript Podcast for convenient understanding

- Global attainment for your research

- Manuscript accessibility in different formats

( Pdf, E-pub, Full Text, Audio)

- Unceasing customer service

Track the below URL for one-step submission

https://juniperpublishers.com/online-submission. 